\section{Deep-sea mining synonymous with wildlife destruction}

The US National Oceans and Atmospheric Administration's infantile comment (Oryx, October 1981, just arrived) on deep-sea mining, that there will be 'little or no potentially harmful effects that must be closely monitored' should be energetically condemned. Deep-sea mining is synonymous with wildlife destruction on a grand scale, and will leave the world with oceans and seas of almost empty water. Mining in the Pacific will swiftly spread to other oceans where the work of stirring up the mud for an unspecified number of years will be devastating for all. Millions of tons of freezing sediment withdrawn from the bed of the sea and dumped back again will hang in suspension for centuries. It will become a steadily increasing ingredient of ocean rivers and currents, and be deposited far and wide in a cloud of death wherever there is sea water, smothering life in abyssal troughs and trenches and turning the continental shelves into a vast submarine Pompeii.

To drum up acceptance of the idea it has been cunningly postulated that sediment returned to the sea at the end of a tube reaching half-way down will make deep-sea mining harmless. Cubic miles of sedimentary waste poured back half-way down are no less deadly than when poured back at the top or at the bottom. Marine life exists at all levels, the half-way down zone being richly endowed with non-migratory as well as migratory species travelling in clouds to the surface and back every twenty-four hours.

Are we to suppose that nodules occur only on the surface of the sea-floor and not at various levels in the sediment (often thousands of feet thick) prompting ever deeper dredging to procure them? In what quantities if any will deadly hydrogen sulphide be released by dredging? How will increasing amounts of sediment swallowed with every mouthful of krill affect the baleen whales for the rest of their lives? Will the growing accumulation of sediment abruptly alter the $\mathrm{pH}$ over vast areas of the sea? Might some sediments prove to be poisonous to marine organisms? The almost endless list of questions without answers should be seen as a strong deterrent to stirring up the mud.

104
The fate of the sea lies with the western nations. It is both sad and criminal that today's scientists seduced by the lure of transitory riches and contemptuous of past errors are again mobilising their treachery to destroy permanently the last and perhaps most beautiful of the world's habitats. The safety of the sea and of the world of tomorrow would be better served by the total rejection of sea mining in favour of an exhaustive and honest study of the abyssal regions first.

Ignorant tampering with the delicate balance established by millions of centuries between the sea's many subhabitats and the single homogeneous mass of shifting sea water covering 70 per cent or 140 million sq miles of the global surface is to defy good sense and embrace danger in its deadliest form.

John Boursot,

12 Calle Poniente No. 1633 ,

Flor Blanca, San Salvador, El Salvador, CA

\section{IWC and horse-trading}

I read with interest the Note on the IWC decision to phase out commercial whaling (Whales: is it victory at last?, Oryx, October 1982). Since then some of the whaling countries have lodged formal objections to that decision and they are no doubt now trying to persuade the others to do so. This was not unexpected and, indeed, the writer is correct in saying that increasing vigilance is necessary. Since the objections were not unexpected by governments seeking to conserve whales it is also evident that they would not in the circumstances have 'given away' large numbers of whales as part of a deal to get the requisite votes for the phase-out. They also are well aware that whether or not the phase-out decision 'sticks' they will have to fight hard for low quotas every year for at least three more years.

It is therefore not helpful to give your readers the impression that there was a massive and cynical trade-off agreed as part of the usual horse-trading in which the IWC engages. Your report is a distortion of what went on in Brighton last July; the facts can speak for themselves, but as a member of the delegation for the Seychelles which was in

Oryx Vol 17 No 2 


\section{Letters}

the thick of the battle I think I am aware of most if not all of the 'negotiations'.

The Note says that a victory price was paid in horse-trading leading to increases in quotas from zero adopted in the Technical Committee to excessively high numbers in the Plenary sessions. But this was inevitable, whether or not the phaseout had been agreed. The zeros were adopted by simple majorities and never had the threequarters majorities necessary for plenary adoption. The changes were in no way 'concessions' but stemmed from the realities of voting rules. The principal difficulty in getting protection for the Spanish fin whales and the Peruvian Bryde's whales was that, as always in recent years, there were disagreements in the scientific advice provided. The real weakness in the IWC procedures is that there is virtually no benefit of doubt given to the whales in situations of scientific uncertainty. And the situation is quite uncertain for all whale stocks that are not yet fully protected. It is true that one or two delegations were trying to convince us that we should 'be magnanimous in victory' after the phase-out vote, but they did not carry with them the majority of nations that had supported the phase-out. We were also faced with blocking votes by Latin American states irrespective of their basic policies concerning whaling.

Your Note also says the phase-out decision can be reversed at any time. Well, of course; all decisions can be changed so long as the IWC continues in existence, and we all want it to continue so that a chaotic free-for-all of whaling can be avoided. But it is important to realise that the decision can only be reversed by a threequarters majority the other way. It seems to me that that is exceedingly unlikely. It could happen, but only if most of the conservationist countries changed their policies completely or left the IWC, and those developments are most unlikely to occur. Changes in just a few of them will make no difference, and it is even possible that some whaling countries will change to our side in future years, as others did in the past and as Spain did this year.

Lastly, I should say there was no serious attempt to change the Bowhead quota, because the present one holds until 1983 at which time we all know that the entire regulatory arrangements for subsistence whaling will have to be reconsidered. Certainly the decision of the overwhelming majority of IWC members not to act regarding the Bowhead was in no way affected by the phaseout decision. No concessions were necessary to the USA because that country was fully behind the moves to negotiate a phase-out.

Of course horse-trading or negotiation, call it what you will, goes on in inter-governmental bodies such as the IWC. But the cause of conservation is hindered, not helped, by allegations implying that countries purporting to have conservationist policies are totally cynical in their actions, and that is the impression I think you are giving your readers.

\section{Sydney Holt, International League for the Protection of Cetaceans}

The inference intended in the Note on whaling was not that the conservationist nations had been cynical but that they had been gullible. Indeed, in the light of the subsequent denunciations by Japan, the USSR, Norway and Peru, this viewpoint could have been made more forcefully. Japan, the USSR, Norway and Peru have refused to accept the victory of the conservation nations, and may even resign from the IWC. So where will the victory be then? It was arguable that we could sacrifice some whale populations now in the hope of saving them all in 1985. But if Japan refuses to co-operate, we shall lose both the present and the future. 'Horse-trading' is, of course, an emotive term, but Dr Holt cannot deny that bargaining goes on all the time at the IWC, and the mistake made by the conservationists at Brighton in 1982 was to go all out for an unenforceable victory in three years' time at the expense of actual and more easily enforceable quotas today.

As regards the possible reversal of the ban: who can tell how many of the more impecunious conservationist members of the IWC will still be members in three years' time? Who, if ourpresent Government is re-elected this year, would even put much money on Britain still being a member?

Richard Fitter,

Vice-Chairman, ffPS 